\title{
Analysis of Variables Affecting Carcass Weight of White Turkeys by Regression Analysis Based on Factor Analysis Scores and Ridge Regression
}

\section{-Author(s)}

\section{Çelik Ş}

Şengül T'

Söğüt B'

Inci $\mathrm{H}^{\prime}$

Şengül AY

Kayaokay A'

Ayaşan $\mathrm{T}^{\mathrm{T}}$

Bingöl University Faculty of Agriculture Dept. of Animal Science-BINGÖL

" Eastern Mediterranean Agricultural Research Institute-ADANA

\section{-Mail Address}

Corresponding author e-mail address Şenol Çelik

Bingöl University Faculty of Agriculture Dept. of Animal Science, Bingöl-Turkey.

Tel: $\quad(+90)$ 426-2160030

E-mail: senolcelik@bingol.edu.tr

\section{EKeywords}

Carcass weight, Carcass parts, factor analysis score based regression, ridge regression, white turkeys.

\section{ABSTRACT}

In this study, the influence of carcass parts weights (thigh, breast, wing, back weight, gizzard, heart, and feet) on whole carcass weight of white turkeys (Big-6) was analyzed by regression analysis based on ridge regression and factor analysis scores. For this purpose, a total of 30 turkey carcasses of 15 males and 15 females with 17 weeks of age, were used. To determine the carcass weight (CW), thigh weight (TW), breast weight (BRW), wing weight (WW), back weight (BW), gizzard weight (GW), heart weight (HW), and feet weight (FW) were used. In the ridge regression model, since the Variance Inflation Factor (VIF) values of the variables were less than 10 , the multicollinearity problem was eliminated. Furthermore, $R^{2}=0.988$ was obtained in the ridge regression model. Since the eigenvalues of the two variables predicted by factor analysis scores were greater than 1 , the model can be explained by two factors. The variance explained by two factors constitutes $88.80 \%$ of the total variance. The regression equation was statistically significant $(p<0.01)$. In the regression equation, two factors obtained by using factor analysis scores were independent variables and standardized carcass weight was considered as dependent variable. In the regression model created by factor analysis scores, the Variance Inflation Factor values were 1 and $R^{2}=0.966$. Both regression models were found to be suitable for predicting carcass weight of turkeys. However, the ridge regression method, which presented higher $R^{2}$ value, has been shown to better explain the carcass weight.

\section{INTRODUCTION}

In Turkey, turkey breeding is a complementary sector to chicken meat production. In addition of offering a flavor alternative to chicken meat, turkey meat is considered an indispensable part of the healthy food trend, establishing a unique consumer market (Cevger \& Türkyılmaz, 2001; Sipahi, 2010).

Turkeys live longer than chickens, have high carcass yields, and can be produced under industrial or grazing systems (Kırkpınar \& Mert, 2004). Growing turkeys have high live body weights, with high edible meat and carcass yields, allowing the production of mass meals and further processed meat products (Kolsarici et al., 1997). The increasing turkey meat consumption in developed countries due to its healthy qualities and low production costs. Compared with chickens, turkeys have leaner meat and higher body weight and carcass yield, other reasons to produce turkeys (Camci \& Sarica, 1991; Ekinci, 1993; Esen, 1993).

Genotype, genetic selection, breeding system, age at slaughter, pre-slaughter treatment, and sex influence carcass yield. It was shown that male turkeys had higher slaughter efficiency than females (Nestor, 1984; Koçak et al., 1990; Sarıca et al., 1996) 
Larsen et al. (1986) reported significant carcass trait differences in turkeys between 12 and 21 weeks of age. Sarıca \& Camci (1993) reported that the carcass yield and breast weight increased from $72 \%$ to $79 \%$, and $27 \%$ to $35 \%$, respectively, between $12-24$ weeks of age. Waldroup et al. (1997) observed increasing live weight and carcass yield as turkeys aged.

Ogah (2011) determined average body weight, body length, and breast circumference as 3.38 and 2.65 $\mathrm{kg}, 35.05$ and $31.86 \mathrm{~cm}$, and 47.38 and $36.62 \mathrm{~cm}$ in males and females of 22-wk-old Nigerian indigenous turkeys, respectively. Ramkrishna et al. (2012) studied three different turkey breeds, and determined average body weights as 3570.35 and $2521.89 \mathrm{~g}$ in 16-wkold male and female turkeys, respectively, as well as average breast, back, thigh, and wing yields of 19.61$19.89 \%, 11.07-11.11 \%, 11.35-11.56 \%$, and $11.61-$ $11.55 \%$ in males and females, respectively. Shamseldin et al. (2014) showed average slaughter weight $(\mathrm{kg})$ and carcass weight $(\mathrm{kg})$ in 16-wk-old male and female turkey reared in semi-intensive and extensive systems as 7.3-6.5 and 6.6-6.1 kg, respectively. In a study with 17-wk-old Converter turkeys, males presented higher live weight and carcass weight than females (Chodová et al., 2014). Ribarski \& Oblakova (2016) evaluated the slaughter and carcass weight of wild turkeys, and also obtained higher values in males than females.

Roberson et al. (2003), evaluating British United Turkeys (BUT), Hybrid and Nicholas turkeys, determined that average body weight and carcass yield were $17.12 \mathrm{~kg}$ and $75.9 \%$ at 18 weeks of age, with no differences among strains. On the other hand, Werner et al. (2008) reported lower carcass weight in slowgrowing compared with fast-growing commercial turkey strains.

The aim of the current study was to investigate the influence of carcass parts (breast, thighs, back, wing, heart, gizzard) weights on the whole carcass weight of White turkeys using Multiple Regression Analysis Techniques obtained with ridge Regression and Factor Analysis Scores.

\section{MATERIALS AND METHODS}

This study was carried out in poultry facilities of Agriculture Faculty in Bingol University, in Turkey. Recorded average environmental temperature and relative humidity were of $27.5^{\circ} \mathrm{C}$ and $44 \%$, respectively.

A total of 30 white males and females turkeys (Big6), 15 males and 15 females, were reared in an opensided house on litter until 17 weeks of age together.
Both males and females received the same diet. A three-phase feeding program was applied. The starter (0-8 weeks), grower (9-14 weeks), and finisher (15-17 weeks of age) diets were formulated to meet the birds' nutritional requirements according to the NRC (1994). Feed and water were offered ad libitum. The composition of the diets manufactured in the experimental facilities is presented Table 1.

Table $\mathbf{1}$ - Ingredients and nutritional composition of the diets.

\begin{tabular}{lccc}
\hline Nutritional composition (\%) & $\begin{array}{c}\text { Starter } \\
(0-8 \\
\text { weeks) }\end{array}$ & $\begin{array}{c}\text { Grower } \\
(9-14 \\
\text { weeks) }\end{array}$ & $\begin{array}{c}\text { Finisher } \\
(15-17 \\
\text { weeks) }\end{array}$ \\
\hline Wheat & 35.00 & 21.00 & 25.00 \\
Maize & 24.50 & 30.00 & 26.00 \\
Barley & 12.00 & 6.50 & 10.00 \\
Fish meal & 2.20 & 3.10 & 2.65 \\
\hline Soybean meal & 23.50 & 22.00 & 16.00 \\
Sunflower seed pod & --- & 5.75 & 10.00 \\
Marble dust & --- & 0.75 & 1.50 \\
Salt & & 0.25 & 0.30 \\
Vitamin premix & 0.15 & 0.25 & 0.20 \\
Mineral premix & 0.15 & 0.15 & 0.10 \\
\hline Meat and bone meal & --- & 7.00 & 4.00 \\
Vegetable oil & 2.50 & 3.25 & 4.25 \\
\hline Total & 100.00 & 100.00 & 100.00 \\
\hline Nutritional composition & \multicolumn{3}{|c}{} \\
\hline Protein (\%) & $26-28$ & $20-23$ & $20-23$ \\
\hline Metabolizable energy (kcal/kg) & $2800-2900$ & $2900-3000$ & $3000-3200$ \\
\hline
\end{tabular}

Vitamin premix=Supplied per kilogram of the diet: vitamin A (retinyl acetate), $8000 \mathrm{IU}$; vitamin D3 (cholecalciferol), $1000 \mathrm{IU}$; vitamin E (DL-a-tocopherol), $30 \mathrm{IU}$; vitamin K3 (menadione dimethylpyrimidinol, 2.5 mg; vitamin B1, 2 mg;

Turkeys were slaughtered at 17 weeks of age, and the following parameters were measured: carcass weight (CW), thigh weight (TW), breast weight (BRW), wing weight (WW), back weight (BW), gizzard weight $(\mathrm{GW})$, heart weight (HW), and feet weight (FW). These measurements were taken out in Facility of Agriculture in Bingol University, in Turkey.

Regression analysis is a statistical technique for research and modeling the relation among variables. These variables are dependent and independent variables (Montgomery et al., 2012).

Multiple linear regression model is as in Equation 1.

$$
Y=X \beta+\varepsilon Y=X \beta+\varepsilon
$$

Where $Y$ is an $(n \times 1)$ column vector of observations belonging to the dependent variable, $X$ is an ( $n x p$ ) fixed matrix of observations if the variables and is of full rank $p(p \leq n), \beta$ is a $(p \times 1)$ unknown column vector of regression coefficients, and $\varepsilon$ is an $n \times 1$ vector of random errors; 


\section{Analysis of Variables Affecting Carcass Weight of White Turkeys by Regression Analysis Based on Factor Analysis Scores and Ridge Regression}

$$
E(\varepsilon)=0 ; E\left(\varepsilon \varepsilon^{1}\right)=\sigma^{2} I_{n} \text {, }
$$

where $I_{n}$ denotes the $n \times n$ identity matrix and the prime denotes the transpose of a matrix (Draper and Smith, 1998). The ordinary least squares (OLS) estimator, $\beta$ of the parameters is obtained by equation 2 (Draper \& Smith, 1998).

$$
\beta=\left(X^{\prime} X\right)^{-1}\left(X^{\prime} Y\right)
$$

$\varepsilon^{\prime}$ s are independently and identically distributed as normal with mean 0 and variance $\sigma^{2}$ (Montgomery et al., 2012).

Ridge regression is a statistical tool used to deal with multicollinearity and to avoid problems related to small sample size and/or a large number of predictor variables (Gruber, 1998; Hastie et al., 2001). Ridge regression is also known as Tikhonov regularization (Tikhonov et al., 1977).

The ridge estimator is shown by (equation 3 ).

$$
\beta_{\mathrm{R}}=\left(X^{\prime} X+k \mathrm{l}\right)^{-1}\left(X^{\prime} Y\right)
$$

where I denotes an identity matrix and $k$ is a positive number determined as ridge parameter.

Alkhamisi \& Shukur (2007) proposed new estimators by adding (equation 4)

$$
\mathrm{k}=\frac{1}{\lambda_{\max }}
$$

to some well-known estimators to estimate the ridge parameter, where $\lambda_{\max }$ is the highest eigenvalue of $X^{\prime} X$.

Multiple regression was used to estimate carcass weight from different carcass part measurements. Factor scores derived from factor analysis were used for multiple regression analysis in order to remove multicollinearity problem (Eyduran et al., 2010). Factors with eigenvalues $>1$ were employed in multiple regression analysis (Tabachnick \& Fidell, 2001; Johnson and Wichern, 2002).

Kaiser-Meyer-Olkin (KMO) measure of sampling adequacy and Bartlett's test of sphericity were applied to determine whether the correlation matrix is an identity matrix, indicating if the factor model is unsuitable (Sharma, 1996). In order to simplify the interpretation of factor loading $(\lambda)$, Varimax rotation was used. Factor coefficients $(F)$ were used to obtain factor scores for selected factors (Eyduran et al., 2010).

The factor analysis equation can be written in matrix form (Equation 5)

$$
Z=\lambda F+\varepsilon
$$

Where $Z$ is a px 1 vector of variables, $\lambda$ is a (pxm) matrix of factor loadings, $F$ is an $(m \times 1)$ vector of factors, and $\varepsilon$ is a (px1) vector of error or residual factors (Sharma, 1996).

Score values of selected factors were considered as independent variables for predicting of carcass weight. The regression equation fitted to standardize carcass weight and factor score values are given Equation 6:

$$
\mathrm{CW}=\mathrm{a}+\mathrm{b}_{1} \mathrm{FS}_{1}+\mathrm{b}_{2} \mathrm{FS}_{2}+\ldots+\mathrm{b}_{\mathrm{k}} \mathrm{FS}_{\mathrm{k}}+\mathrm{e}
$$

Where $a$ is the regression constant (the value of the intercept and its value is zero); $b_{1}, b_{2}$ and $b_{k}$ are the regression coefficients of factor scores (FS). FS is factor score and e is the error term. Regression coefficients were tested by a t-statistics. The quality of the regression was determined by the coefficient of determination $\left(R^{2}\right)$ (Draper \& Smith, 1998).

\section{RESULTS}

As shown in Table 2, the linear relationship between carcass weight and carcass values was $99.8 \%$ in the multiple regression equation obtained by the least squares (LSM) method. The measured weights explain $99.5 \%$ of the carcass weight variation. There were no autocorrelation problems in the regression model, where Durbin-Watson statistics were observed as 2.101. The regression model was statistically significant $(p<0.001)$.

Table 2 - Multiple regression analysis of variance, goodness of fit and standard error values obtained from least squares means.

\begin{tabular}{lccccc}
\hline Model & SS & df & MS & $F$ & $p$ \\
\hline Regression & 74310251.269 & 7 & 10615750.181 & 659.894 & 0.001 \\
Residual & 353915.431 & 22 & 16087.065 & & \\
Total & 74664166.700 & 29 & & & \\
\hline
\end{tabular}

$r$ (correlation coefficients) $=0.998, R^{2}=0.995$, Adjusted $R^{2}=0.994$, Std. Error of the Estimate $=126.835$, Durbin-Watson=2.101. df: degrees freedom, F: F test, p: significant, SS: sum of squares, MS: mean square

In this study, the standard error of the constant term was found to be high, according to the least squares coefficient results, as shown in Table 3. When Table 3 was examined, the regression relation obtained as the result of LSM was statistically significant $(p<0.01)$. The standard error of the parameters of the regression model shown in Table 3 was high and the coefficients of some parameters were statistically insignificant. Also, some variables (thigh and wing weights) have multiple connection problems because VIF values were greater than 10 . The correlation matrix presented in Table 4 has correlation coefficients higher than 0.90 . For these reasons, the ridge regression method was applied to estimate the carcass weight of turkeys. 
Table 3 - Estimated regression parameter, significance level, tolerance and VIF values obtained from least squares means.

\begin{tabular}{|c|c|c|c|c|c|c|}
\hline Parameters & $B$ & SE & $t$ & $p$ & Tolerance & VIF \\
\hline (Constant) & 153.372 & 237.281 & 0.646 & 0.525 & & \\
\hline TW & 1.104 & 0.245 & 4.496 & 0.000 & 0.064 & 15.644 \\
\hline BRW & 0.955 & 0.099 & 9.690 & 0.000 & 0.120 & 8.309 \\
\hline WW & 0.563 & 0.433 & 1.302 & 0.206 & 0.082 & 12.225 \\
\hline BW & 1.208 & 0.175 & 6.900 & 0.000 & 0.131 & 7.638 \\
\hline GW & -0.353 & 1.535 & -0.230 & 0.820 & 0.514 & 1.945 \\
\hline $\mathrm{HW}$ & 5.859 & 5.518 & 1.062 & 0.300 & 0.224 & 4.472 \\
\hline FW & 0.207 & 0.811 & 0.255 & 0.801 & 0.154 & 6.498 \\
\hline
\end{tabular}

TW: thigh weight, BRW: breast weight, WW: wing weight, BW: back weight, GW: gizzard weight, HW: heart weight, FW: feet weight. SE: standard error. VIF: variance inflation factor, B: regression parameter, t: t-test statistics

Table 4 - Correlations between independent variables.

\begin{tabular}{lccccccc}
\hline & TW & BRW & WW & BW & GW & HW & FW \\
\hline TW & 1 & $0.800^{* *}$ & $0.943^{* *}$ & $0.825^{* *}$ & -0.029 & $0.857^{* *}$ & $0.853^{* *}$ \\
BRW & $0.800^{* *}$ & 1 & $0.765^{* *}$ & $0.912^{* *}$ & -0.328 & $0.780^{* *}$ & $0.553^{* *}$ \\
WW & $0.943^{* *}$ & $0.765^{* *}$ & 1 & $0.789^{* *}$ & -0.104 & $0.799^{* *}$ & $0.849^{* *}$ \\
BW & $0.825^{* *}$ & $0.912^{* *}$ & $0.789^{* *}$ & 1 & -0.173 & $0.806^{* *}$ & $0.620^{* *}$ \\
GW & -0.029 & -0.328 & -0.104 & -0.173 & 1 & -0.087 & 0.232 \\
HW & $0.857^{* *}$ & $0.780^{* *}$ & $0.799^{* *}$ & $0.806^{* *}$ & -0.087 & $0.728^{* *}$ \\
FW & $0.853^{* *}$ & $0.553^{* *}$ & $0.849^{* *}$ & $0.620^{* *}$ & 0.232 & $0.728^{* *}$ & 1 \\
\hline
\end{tabular}

$* *$ : Correlation is significant at the 0.01 level (2-tailed).

TW: thigh weight, BRW: breast weight, WW: wing weight, BW: back weight, GW: gizzard weight, HW: heart weight, FW: feet weight.

Table 5 - The goodness of fit results in ridge regression $(\mathrm{k}$ $=0.204)$.

\begin{tabular}{lccc}
\hline$r$ & $R^{2}$ & Adj. $R^{2}$ & $S E$ \\
\hline 0.994 & 0.988 & 0.984 & 202.184 \\
\hline
\end{tabular}

$r$ : correlation coefficient, $R^{2}$ : coefficient of determination, Adj. $R^{2}$ : adjusted coefficient of determination, SE: standard error, $\mathrm{k}$ : bias constant

Using the equation (5), the value of the $k$ bias constant was approximately $k=0.204$. Table 6 shows the ridge regression goodness of fit and standard error values with $k=0.204$ bias constant. Using the ridge regression technique and $k$ bias of 0.204 , the relationship between carcass weight and carcass parts was $99.4 \%$. Table 4 shows that $98.40 \%$ of the variation in carcass weight is explained by the carcass parts. It is shown in Table 5 that the correlation with ridge regression was statistically significant $(p<0.01)$.

Table 6 - ridge regression variance analysis results.

\begin{tabular}{lccccc}
\hline & df & SS & MS & $F$ & $p$ \\
\hline Regression & 7 & 73764841 & 10537834 & 257.785 & 0.001 \\
Residual & 22 & 899325.85 & 40878.448 & & \\
General & 29 & 74664166.85 & & & \\
\hline
\end{tabular}

$\mathrm{df:}$ degrees freedom, SS: sum of squares, MS: mean square, F: $\mathrm{F}$ test, p: significance level

The predicted parameters of the ridge regression result differ from those obtained with the LSM method. There was a significant decrease in the standard errors and VIF values of the parameters of the ridge regression equation. Thus, a reliable and accurate regression prediction equation was obtained (Table 7).

Table 7 - Ridge regression parameters, standard errors and VIF values

\begin{tabular}{lccccc}
\hline Parameters & $\begin{array}{c}\text { Regression } \\
\text { Coefficient }\end{array}$ & SE & Beta & B/SE(B) & VIF \\
\hline (Constant) & 743.340 & 271.223 & 0 & 2.741 & \\
TW & 0.742 & 0.080 & 0.175 & 9.218 & 2.781 \\
BRW & 0.692 & 0.049 & 0.297 & 14.045 & 1.084 \\
WW & 1.052 & 0.171 & 0.125 & 6.145 & 3.129 \\
BW & 1.131 & 0.093 & 0.262 & 12.105 & 1.331 \\
GW & -2.727 & 1.482 & -0.036 & -1.840 & 8.766 \\
HW & 19.216 & 4.179 & 0.108 & 4.598 & 4.681 \\
FW & 1.068 & 0.465 & 0.049 & 2.297 & 6.036 \\
\hline
\end{tabular}

TW: thigh weight, BRW: breast weight, WW: wing weight, BW: back weight, GW: gizzard weight, HW: heart weight, FW: feet weight SE: standard error. VIF: variance inflation factor, B: regression parameter, Beta: standardized regression parameter

Another way to estimate carcass weight and to determine the factors that affect carcass weight is the regression model, which is created using factor analysis scores. Bartlett's test for sphericity was performed to check the separability of the correlation matrix to the factors. Since the Bartlett test results were $p<0.001$, we found that the data presented multiple normal distributions. Since the estimated KMO (Kaiser-MeyerOlkin) coefficient was 0.826 , the sample size in the study was sufficient (Table 8). 
Table 8 - KMO and Bartlett's Test.

\begin{tabular}{lcc}
\hline \multicolumn{2}{l}{ Kaiser-Meyer-Olkin measure of sampling adequacy } & 0.826 \\
\hline \multirow{3}{*}{ Bartlett's Test of Sphericity } & Approx. Chi-Square & 230.242 \\
& $\mathrm{df}$ & 21 \\
& $\mathrm{p}$ & 0.001 \\
\hline
\end{tabular}

$\mathrm{df:}$ degrees freedom, $\mathrm{p}$ : significance level

In order to determine the number of significant factors in the application of factor analysis, the variance explanatory percentages of total variance and factors is given in Table 9.

Table 9 - Total variance explained.

\begin{tabular}{lccc}
\hline & Component 1 & Component 2 & Communality \\
\hline TW & 0.972 & 0.037 & 0.946 \\
WW & 0.946 & -0.010 & 0.894 \\
HW & 0.909 & -0.059 & 0.830 \\
BRW & 0.896 & -0.226 & 0.853 \\
FW & 0.864 & 0.369 & 0.883 \\
BW & 0.862 & -0.382 & 0.889 \\
GW & -0.044 & 0.957 & 0.917 \\
Variance & 4.960 & 1.254 & 6.214 \\
\% Variance & 0.708 & 0.179 & 0.888 \\
\hline
\end{tabular}

TW: thigh weight, BRW: breast weight, WW: wing weight, BW: back weight, GW: gizzard weight, HW: heart weight, FW: feet weight

According to the factor analysis results presented in Table 8, the eigenvalues of the first 2 out of 7 predicted factors were higher than 1 , and therefore, can be used as independent variables in multiple regression analysis. At the beginning, $88.8 \%$ of the total variance was explained with 2 factors instead of 7 variables. This value is suitable for determining the optimum number of factors. The total variance ratio described should be at least 2/3 (67\%) (Tabachnick \& Fidell, 2001). Considering that the total variance value described here was higher than $2 / 3$ (0.888), the factors considered account for the total variance was at a sufficient level.

Turned factor loads indicate the relationship between independent variables and factors examined. The highest correlations were estimated between thigh, wing, heart, back weight, feet and breast weights in Factor 1 (0.972, 0.946, 0.909, 0.896, 0.864 and 0.862), and gizzard in Factor 2. In addition, the variance of the variables was reflected effectively, as the amounts of commonality were high. The first two factors considered explained $70.8 \%$ and $17.9 \%$ of the total variance in all variables, respectively. Factor score coefficients were given in Table 10. According to these coefficients, the factor score for each animal was established according to 2 factors.
Table 10 - Component Score Coefficient Matrix.

\begin{tabular}{lcc}
\hline Traits & Factor 1 & Factor 2 \\
\hline TW & 0.200 & 0.074 \\
BRW & 0.158 & -0.269 \\
WW & 0.193 & 0.035 \\
BW & 0.173 & -0.142 \\
GW & 0.035 & 0.771 \\
HW & 0.183 & -0.006 \\
FW & 0.193 & 0.338 \\
\hline
\end{tabular}

TW: thigh weight, BRW: breast weight, WW: wing weight, BW: back weight, GW: gizzard weight, HW: heart weight, FW: feet weight.

The factor scores obtained from the factor analysis were used as independent variables to estimate the carcass weight of turkeys and the findings obtained to determine the important factors in carcass weighting are given in Table 11.

Table 11 - Factor Analysis Scores variance analysis results.

\begin{tabular}{lccccc}
\hline Parameters & Coefficients & Std. Error & $t$ & $p$ & VIF \\
\hline FS1 & 0.959 & 0.035 & 27.145 & 0.001 & 1.000 \\
FS2 & -0.214 & 0.035 & -6.059 & 0.001 & 1.000 \\
\hline
\end{tabular}

$r=0.983, R^{2}=0.966$, Adj. $R^{2}=0.964, S=0.190, F=386.780, p<0.01, d=1.854, F S:$ Factor score

r: correlation coefficient, $R^{2}$ : coefficient of determination, Adj. $R^{2}$ : adjusted coefficient of determination, SE: standard error, VIF: variance inflation factor, d: Durbin-Watson statistics, FS1: Factor 1, FS2: Factor 2.

According to the results of the regression analysis with the factor scores shown in Table 11, the effect of the two factors used as independent variables to estimate the carcass weight of turkeys was statistically significant $(p<0.01)$. With the use of factor scores in the model, the multicollinearity problem was solved, and $\mathrm{VIF}=1$ was found. Factor scores used in the model explained $96.6 \%$ of the total variation of white turkey carcass weights. The model was found to be generally significant $(F=386.780$ and $p<0.01)$. There was no autocorrelation problem since the Durbin-Watson $d$ statistic was 1.854. After these results, the carcass weight estimation equation can be established and, it is expressed as:

\section{$C W=0.959$ FS1-0.214 FS2}

It is expected that white turkeys with higher thigh, wing, heart, back, feet, and breast weight values have higher carcass weight because of similar signs of rotated factor loads and regression coefficients of factor scores. Here, thigh weight, wing weight, heart weight, back weight, feet weight, and breast weight were positively related with carcass weight. However, gizzard weight was negatively related with carcass weight. In other words, the carcass weight was positive in FS1 and negative in FS2. 
Çelik Ş, Şengül T, Söğüt B, Inci H, Şengül AY, Kayaokay A, Ayaşan T

\section{Analysis of Variables Affecting Carcass Weight of White Turkeys by Regression Analysis Based on Factor Analysis Scores and Ridge Regression}

\section{DISCUSSION}

According to Wicks et al. (2000), about $90 \%$ of turkey meat produced in Germany was based on heavy processing turkeys. Werner et al. (2008) determined that fast-growing turkeys (BUT=British United Turkeys Ltd. Big 6 and Kelly BBB=Kelly Broad-Breasted Bronze) presented carcass weights of 15.5 and $12.9 \mathrm{~kg}$, respectively.

In the study of İşüzar (2003), at 18 weeks of age, average body weights of bronze and white turkeys (males and females) were 7495-4843 $\mathrm{g}$ and 15844$11797 \mathrm{~g}$, with average carcass weights of 5445$3548 \mathrm{~g}$ and 13107-9676 g, respectively. Lemme et al. (2004) reported carcass weights and carcass yields of 140-d-old male Big 6 turkeys between $13.19-13.89 \mathrm{~kg}$ and $71.24-72.7 \%$.

Our results agree with Yakubu et al. (2009), who using the Varimax rotated factor analysis, extracted two factors which explained $87.53 \%$ of the total variability in the body measurements of chickens.

Variance proportions explained by 3 factor scores were found to be $97 \%$ for male and $96 \%$ in female turkeys, respectively, in study of Ogah (2011), as well as $R^{2}$ values of 53.93 and 78.95 for male and female turkeys, respectively. In the current study, variance explanation rate was lower and $\mathrm{R}^{2}$ value was higher than those verified by Ogah (2011).

Eyduran et al. (2013) reported a Kaiser-MeyerOlkin values of 0.60 , which also confirmed that the factor analysis was applicable to their data. Factor analysis scores obtained by multiple regression analysis reflected that five factors explained $87.7 \%$ of variation and had an $R^{2}=0.65$. The number of factors and the total variance value in the present study were very close to the values obtained by Eyduran et al. (2013), but $\mathrm{R}^{2}$ was higher.

Body weight as determined by morphological characteristics was predicted by factor scores. $\mathrm{R}^{2}(\%)$, adjusted $R^{2}(\%)$, and RMSE values for weight prediction were estimated as very high using $\operatorname{MLRA}(87.8,87.6$, and 0.352 for male sheep, and 92.0,91.9, and 0.284 for female sheep) as MLRA removed the multicollinearity problem (Khan et al., 2014). The value of $R^{2}$ in our study was higher.

Beyhan et al. (2016) reported that four factors influenced the core weight of plants by multiple regression method using factor analysis scores, and determined $95.3 \%$ of the total variance and $R^{2}=$ 0.947 . The values obtained in the current study were slightly lower than those obtained in that study.
The use of interdependent explanatory variables should be treated with caution, since multicollinearity has been shown to be associated with unstable estimates of regression coefficients (Yakubu, 2009), rendering the estimation of single effects of these predictors impossible. In order to eliminate multicollinearity problems, multiple regression analysis after factor analysis was used for male and female turkey data sets. This verifies the use of factor scores for prediction. Factors that are orthogonal to each other are more reliable for estimating outputs.

Although there are many studies in literature using factor analysis scores in multivariate regression analysis of different animals (Keskin et al., 2007; Eyduran et al., 2009; Yakubu et al., 2009; Eyduran et al., 2013), very few were found on turkeys (Ogah, 2011). Briefly, it was not possible to compare the results of the present study with earlier studies due to use of different species, traits, sample sizes, and various statistical analysis methods.

\section{CONCLUSION}

The use of factor analysis scores of principal component scores in multiple regression and ridge regression models simplifies the fit of multiple regression models by reducing the number of variables, as well as the interpretation of multiple regression model results by removing indirect effects of related explanatory variables. Both regression models showed better results than the multiple linear regression method. However, the ridge regression method, which yielded a higher $\mathrm{R}^{2}$ value, presented a better explanation of turkey carcass weight.

\section{REFERENCES}

Alkhamisi MA, Shukur G. A Monte Carlo study of recent ridge parameters. Communications in Statistics, Simulation and Computation 2007;36(3):535-547.

Beyhan Ö, Eyduran E, Akın M, Ercişli S, Geçer MK, Karahan AE Identification of the relationship between some characteristics of native walnut genotypes peculiar to Darende district of Malatya province: use of factor analysis scores in multiple linear regression. Genetika 2016;48(3):923 $-932$

Camcı O, Sarica M. Entansif hindi yetiştiriciliği. TiGEM 1991;36(1):5-19.

Cevger Y, Türkyılmaz K. Türkiye'de hindi eti ve önemi. Veteriner Hekimler Derneği Dergisi 2001;70(3):1-11.

Chodová D, Tůmová E, Svobodová J, Uhlírová L. Differences in carcass composition of males and females of two turkey hybrids. Acta Fytotechnica et Zootechnica 2014;17(3):72-74.

Draper NR, Smith H. Applied regression analysis. New York: John Wiley and Sons; 1998. 
Çelik Ş, Şengül T, Söğüt B, Inci H, Şengül AY, Kayaokay A, Ayaşan T
Analysis of Variables Affecting Carcass Weight of White Turkeys by Regression Analysis Based on Factor Analysis Scores and Ridge Regression
Ekinci S. Ülkemizde hindicilik. Tarım ve Köy Dergisi 1993:86(1):20-21.

Esen K. Hindicilik. TIGEM 1993;8(1):47.

Eyduran E, Karakus K, Karakus S, Cengiz F. Usage of factor scores for determining relationships among body weight and body measurements. Bulgarian Journal of Agricultural Science 2009;15(4):374378.

Eyduran E, Topal M, Sonmez AY. Use of factor scores in multiple regression analysis for estimation of body weight by several body measurements in Brown trouts (Salmo trutta fario). International Journal of Agriculture and Biology 2010;12(4):611 615

Eyduran E, Yilmaz I, Kaygisiz A, Aktas MZ. An investigation on relationship between lactation milk yield, somatic cell count and udder traits in first lactation Turkish saanen goat using different statistical techniques. The Journal of Animal Plant Sciences 2013;23(4):956-983.

Gruber MHJ. Improving efficiency by shrinkage: the James-Stein and ridge regression estimators. New York: Marcel Dekker; 1998.

Hastie T, Tibshirani R, Friedman J. The elements of statistical learning: data mining, inference, and prediction. New York: Springer; 2001.

Işgüzar E. Growth, carcass traits and meat quality of bronze and white turkeys in Isparta province of Turkey. Archiv Tierzucht 2003;46(5):471481.

Johnson RA, Wichern DW. Applied multivariate statistical analysis. New Jersey: Prentice Hall, upper Saddle River; 2002. 766 p.

Keskin S, Daskiran I, Kor A. Factor analysis scores in a multiple linear regression model for the prediction of carcass weight in Akkeci kids. Journal of Applied Animal Research 2007;31(2):201-204.

Khan MA, Tariq MM, Eyduran E, Tatliyer A, Rafeeq M, Abbas F, et al. Estimating body weight from several body measurements in Harnai sheep without multicollinearity problem. The Journal of Animal and Plant Sciences, 2014;24(1):120-126.

Kırkpınar F, Mert S. Etlik hindi üretiminin temel ilkeleri. Hasat, Hayvancılık Dergisi 2004;2(9):24-27.

Koçak C, Gönül T, Sarıcan C, Öz M. Bronz ve Bronz x Betina melez hindilerinde gelişsme ve karkas özellikleri üzerine araştırmalar. Doğa Türk Veterinerlik Hayvancilik 1990;14(2):158-165.

Kolsarici N, Turhan K, Çakmakçı L, Elibol O. Kanatlı et ürünleri üretim teknolojileri. Istanbul: Uluslararası Tavukçuluk Kongresi; 1997. p.137155.

Larsen JE, Adams RL, Peng IC, Stadelman WJ. Growth, feed conversion and yields of turkey parts of three strain of hen turkeys as influenced by age. Poultry Science 1986;65(11):2076-2081.

Lemme A, FrackenpohI U, Petri A, Meyer H. Effects of reduced dietary protein concentrations with amino acid supplementation on performance and carcass quality in turkey toms 14 to 140 days of age. International Journal of Poultry Science 2004;3(6):391-399.

Montgomery DC, Peck EA, Vining GG. Introduction to linear regression analysis. New York: Wiley and Sons; 2012.

Nestor KE. Genetics of growth and reproduction in the Turkey. Longterm selection for increase 16 . week body weight. Poultry Science 1984;63(11):2114-2122.
NRC. Nutrient requirements of poultry. 9th ed. Washington: National Academy Press; 1994.

Ogah DM. Assessing size and conformation of the body of Nigerian indigenous turkey. Slovak Journal Animal Science;2011;44(1):21-27.

Ramkrishna RS, Sheriff FR, Manohar GR. Growth performance and carcass yields as influenced byage and sex in different turkey varieties. Tamilnadu Journal Veterinary Animal Sciences 2012;8(2):94-100.

Ribarski S, Oblakova M. Slaughter yield and quality of meat from wild turkey (Meleagris Gallopavo Silvestris Vieillot) reared in hunting reserve in South Bulgaria. Trakia Journal of Sciences 2016;14(2):135-141.

Roberson Rahn, AP, Balander RJ, Orth MW, Smith DM, Booren BL, Booren $A M$, et al. Evaluation of the growth potential, carcass components and meat quality characteristics of three commercial strains of Tom Turkeys. Journal of Applied Poultry Research 2003;12:229-236.

Sarıca M, Testik A, Saylam SK, Karaçay N, Celen MF. Canlı ağırlık yönünden seleksiyonun hindilerin büyüme ve üreme özelliklerine etkileri. Ulusal Kümes Hayvanları Sempozyumu;1996; Çukurova, Adana. Turkey: Üniversitesi Ziraat Fakültesi; 1996.

Sarıca M, Camcı Ö. Hindilerde et verimi ve karkas kompozisyonuna etki eden faktörler. Teknik Tavukçuluk Dergisi 1993;180:22-28.

Sharma S. Applied multivariate techniques. New York: John Wiley and Sons; 1996.

Sipahi C. Entansif hindi yetiştiriciliği işletmelerinde karlılık ve verimlilik analizleri [tezi]. Ankara (TK): ÜniversitesivSağılık Bilimleri Enstitüsü; 2010.

Shamseldin RM, Gibril S, Atta M, Yassin OE, Hassan AA. Effect of rearing system, slaughter age and sex on turkey (Meleagris gallopavo) carcass component percentages. Research Opinion Animal Veterinary Science 2014;4(4):198-202

Tabachnick BG, Fidell LS. Using multivariate statistics. Boston: Allyn and Bacon Pearson Education Company Boston; 2001.

Tikhonov A, Arsenin V, John F. Solutions of ill-posed problems. Washington: VH Winston; 1977.

Waldroup PW, Adams MH, Waldroup AL. Evaluation of national research council amino acid recommendations for large white turkeys. Poultry Science 1997;76(5):711-720.

Werner C, Riegel J, Wicke M. Slaughter performance of four different turkey strains, with special focus on the muscle fiber structure and the meat quality of the breast muscle. Poultry Science 2008;87(9):18491859.

Wicke M, Hahn G, Maak S, Von Lengerken G. Physiologische grenzen des wachstums bei schweinen und geflügel - auch ein problem nachhaltiger fleischerzeugung. In: Baff (HRSG). Fleisch im Umfeld von Ökologie und Nachhaltigkeit. Kulmbacher Reihe 2000;17:70-88.

Yakubu A. Fixing collinearity instability in the estimation of body weight from morpho-biometrical traits of West African Dwarf goats. Trakia Journal of Sciences 2009;7:61-66.

Yakubu A, Idahor K O, Agade Y I. Using factor scores in multiple linear regression model for predicting the carcass weight of broiler chickens using body measurements. Revista UDO Agricola 2009;9(4):963-967. 
